IP Periodica Polytechnica Civil Engineering

\author{
59(4), pp. 567 573, 2015 \\ DOI: $10.3311 /$ PPci.7786 \\ Creative Commons Attribution (1) \\ RESEARCH ARTICLE
}

\section{Numerical Testing of a Small-Scale Stone Masonry Arch}

\author{
Gyula Bögöly, Péter Görög
}

Received 31-10-2014, revised 18-02-2015, accepted 03-03-2015

\begin{abstract}
This paper presents the required preparatory investigations for the construction of a masonry vault model experiment under laboratory conditions. The analyzed factors included structural design, material, loading and geometry of the model. A numerical modelling was made by Phase $e^{2}$ finite element program to check the performance of the masonry vault and the failure criteria. The results show that the connections of the masonry elements have considerable influence on the behaviour of small scale vaults. Thus the effect of the tensile strength of the connections was analysed in particular. The paper presents the different failure mechanisms and behaviours of continuum shells and masonry shells. Additionally, the behaviour of the partly cracked connections has been analysed.
\end{abstract}

\section{Keywords}

masonry arch $\cdot$ small scale laboratory experiment $\cdot$ numerical model $\cdot$ mechanical behaviour $\cdot$ connections

\section{Gyula Bögöly}

Department of Engineering Geology and Geotechnics, Budapest University of Technology and Economics, H-1111 Budapest, Múegyetem rkp. 3, Hungary e-mail: bogoly.gyula@epito.bme.hu

\section{Péter Görög}

Department of Engineering Geology and Geotechnics, Budapest University of Technology and Economics, H-1111 Budapest, Múegyetem rkp. 3, Hungary e-mail: gorog.peter@epito.bme.hu

\section{Introduction}

Maintenance and restoration are common problem of historical stone structures. There are more than 1500 stone masonry arch bridges in Hungary which were built primarily in the 18th and 19th centuries [1]. Since the condition of most bridges aggravated and the traffic loads have increased significantly, the verification of the stability and the calculation of the load-bearing capacity of these bridges are required. Thus several Hungarian stone masonry arch bridges were investigated in the past few years [2-9]. It has been found that it is difficult to determine adequate input parameters for the numerical modelling from the in situ tests even for simple methods such as thrust line analysis. Naturally, the more complex methods require more precise input parameters. Nonetheless, the results of these more complex models describe better the behaviour of the masonry vaults. All things considered, great accuracy is expected from the numerical models, though it is not attained in case of practical applications. In general, it is very difficult to obtain the input parameters which can modify the results significantly. Therefore it is important to determine the scale of these effects and get to know their behaviour better by means of laboratory and numerical experiments.

Within the masonry vaults predominantly compression, and in a smaller extent shear and friction occur from the external loads. The main point in design of arch geometries is to allow the smallest tension to occur, since the connections of real masonry arches usually do not resist high tensions. If a vault is capable of bearing a significant tensile stress, then it is a continuum shell rather than a masonry shell. Thus the bonding strength of the connections influences the behaviour of the arches significantly. In case of small scale laboratory experiments the bonding strength has a more important influence on the stability of the structure. As a consequence, this parameter was analysed by means of numerical modelling.

The aim of this paper is to provide information about the required parameters for the analysis of the behaviour of stone arches by means of experiments. To increase the reliability of models and to have a better accuracy of the input parameters scale laboratory experiments are required with the combination 
of numerical modelling. With the help of the small scale experiments the general behaviour of each structural element and connection can be better understood. Previous studies dealt with real and small scale laboratory models and their numerical analyses with rigid-block method [10,11]; or with FEM [12,13] and with DEM [14]. Prior to the laboratory experiments preliminary computer analyses are advised, since these computer-derived models help to design the experiments and allow a better understanding of failure mechanisms. This paper will address the different aspects and results of the preparatory investigations of a small scale laboratory experiment.

\section{Analytical method}

\subsection{Geometrical design}

Most of the Hungarian masonry arch bridges (app. 90\%) are single-span bridges [15], and a significant part of the multispan bridges have short piers, i.e. their piers have low slenderness ratios. The spans of this kind of multi-span bridges work separately as independent arches so they could be investigated like single-span bridges [15]. Therefore in the first phase of our planned experiments the aim of the research was to investigate single-span barrel vaults. Although, barrel vaults are three-dimensional shell structures, when the vaults have joints that pass through the direction of axis, the verification of the load-bearing capacity can be simplified. The three-dimensional numerical modelling can be reduced to a two-dimensional task to close approximation. Fig. 1 shows the geometry of the chosen arch which consists of 14 blocks. The size of the blocks are: $6.5 \mathrm{~cm} * 12 \mathrm{~cm}$.

\subsection{Material properties}

Hungarian stone masonry arches do not have one typical dimension stone. Usually they were constructed from different dimension stones of that region [1, 17], and very often different lithologies were used. Their span is typically small, and local builders used mostly stones form the neighbouring quarries. Therefore in our experiment there were no preferred lithologies. The aim of the material selection was to use such material that behaved homogeneously and isotropicly even in a small scale. This was the primary consideration because the internal structure of the rocks could influence the whole behaviour significantly depending on the size [18]. With homogeneous material the evaluation of the results becomes more certain for both the experimental and the numerical models. For this reason the laboratory arch is planned to be built from a stone that has fairly homogeneous micro-fabric. It could be fine-grained quartz sandstone or certain types of limestone [19].

To adjust the behaviour of the connections the angle of internal friction, cohesion, tensile strength, normal and shear stiffness are needed. The input parameters of the models of the arches are shown in Table 1 . Different parameter settings were used to analyse the different behaviours, therefore in case of the connections the following tensile strength values were used: $\sigma_{t}=0,0.025,0.05,0.075,0.1,0.2,0.3$ and $0.6 \mathrm{MPa}$.

\subsection{Loading}

The fill and backfill of masonry arch bridges influence the structural behaviour of the vault significantly, since they have both stabilizing and load distributing function [4, 20]. Therefore these effects have to be considered in order to get a result that best models the behaviour of the masonry arch. Currently the soil-structure interaction is in the focus of research [11,12]. However, our aim was to eliminate the complex effect of the arch-backfill interaction phenomena, therefore two symmetrically placed concentrated forces were chosen as loads (Fig. 1). With this simplification it was easier to observe and analyse the effect and behaviour of the different parameters.

\subsection{Numerical modelling}

For the preparatory investigations of our experiment the Phase $^{2}$ finite element program was used. It is a 2-dimensional elasto-plastic finite element program for calculating stresses and displacements around underground openings, and can be used to solve a wide range of mining, geotechnical and civil engineering problems [21]. Plane strain analysis was used with homogeneous isotropic linear elastic 6 noded triangle finite elements. The connections between the blocks were taken into account as joints. A joint represents an interface along which movement could take place. A joint was assigned strength and stiffness properties in accordance with the Mohr-Coulomb failure criterion.

\section{Results}

\subsection{Connections between masonry blocks}

\subsubsection{Tensile strength}

By changing the value of the tensile strength of the connections, it can be studied how the structure would behave in case of different bonding strengths $\left(\sigma_{t}=0,0.025,0.05,0.075,0.1,0.2,0.3\right.$ and $\left.0.6 \mathrm{MPa}\right)$. Examples for the models made by Phase $^{2}$ are shown in Fig. 2]-7

Fig. 2-4 show the failure of arches which behave rather like masonry shells, i.e. the connections of the arches have zero or small tensile strength $\left(\sigma_{t}=0,0.05,0.075 \mathrm{MPa}\right)$. Fig. 5-7 7 shows the failure of arches which are considered as continuum shells, i.e. the connections of the arches have large tensile strength $\left(\sigma_{t}=0.1,0.2,0.6 \mathrm{MPa}\right)$. On the figures the total displacement of arches are shown at the moment of the collapse, where the displacements increase from black to white. The failure loads are also demonstrated. Additionally, white lines mark the cracked parts of the connections within the original geometry. The deformed shapes are also indicated with grey contours on all figures.

Table 2 demonstrates the effect of the tensile strength of the connections on the failure load, the maximum displacement and the number of the cracked connections. Additionally, it shows 
Tab. 1. Input data of the $\mathrm{Phase}^{2}$ models of the arches

\begin{tabular}{|c|c|c|c|c|c|c|}
\hline \multicolumn{7}{|c|}{ Properties of the blocks: } \\
\hline$\gamma\left[\mathrm{kN} / \mathrm{m}^{3}\right]$ & $\mathrm{E}[\mathrm{GPa}]$ & $v[-]$ & $\sigma_{t, \max }[\mathrm{MPa}]$ & $\sigma_{t, \min }[\mathrm{MPa}]$ & $\varphi_{\max }\left[^{\circ}\right]$ & $\mathrm{c}_{\max }[\mathrm{MPa}]$ \\
\hline 20.0 & 6.7 & 0.3 & 10.0 & 0.0 & 50.0 & 15.0 \\
\hline \multicolumn{7}{|c|}{ Properties of the connections: } \\
\hline$\sigma_{t}[\mathrm{MPa}]$ & $\varphi\left[^{\circ}\right]$ & $\mathrm{c}[\mathrm{MPa}]$ & \multicolumn{2}{|c|}{ Normal stiffness $[\mathrm{MPa} / \mathrm{m}]$} & \multicolumn{2}{|c|}{ Shear stiffness $[\mathrm{MPa} / \mathrm{m}]$} \\
\hline various & 35.0 & 0.0 & \multicolumn{2}{|c|}{600000} & \multicolumn{2}{|c|}{277000} \\
\hline
\end{tabular}

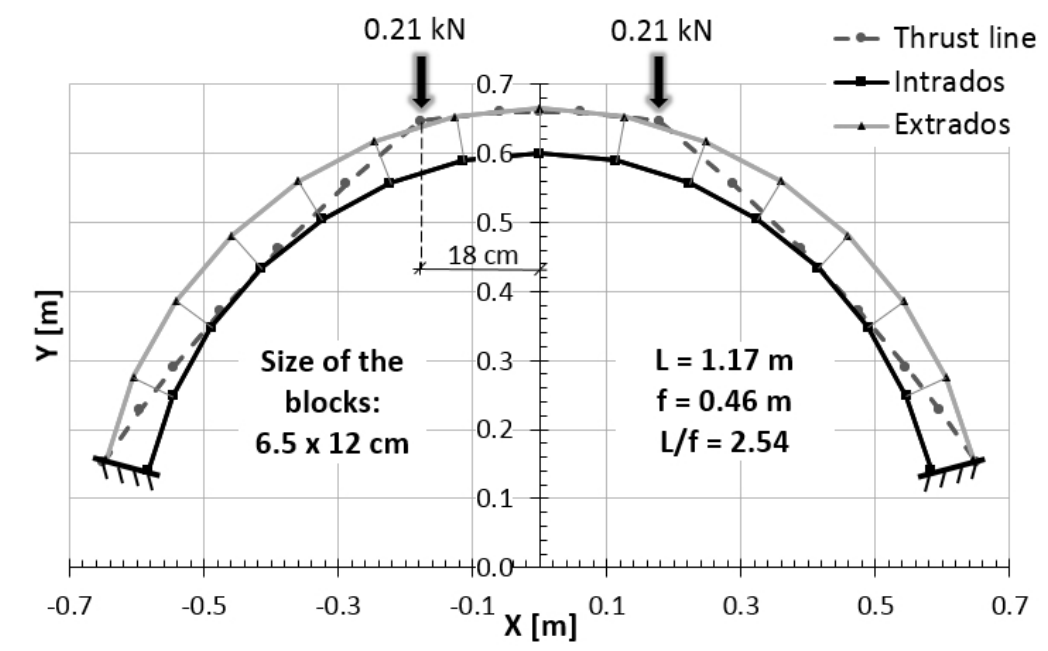

Fig. 1. Chosen geometry $(\mathrm{L} \sim \operatorname{span}, \mathrm{f} \sim$ rise) (by $[16])$

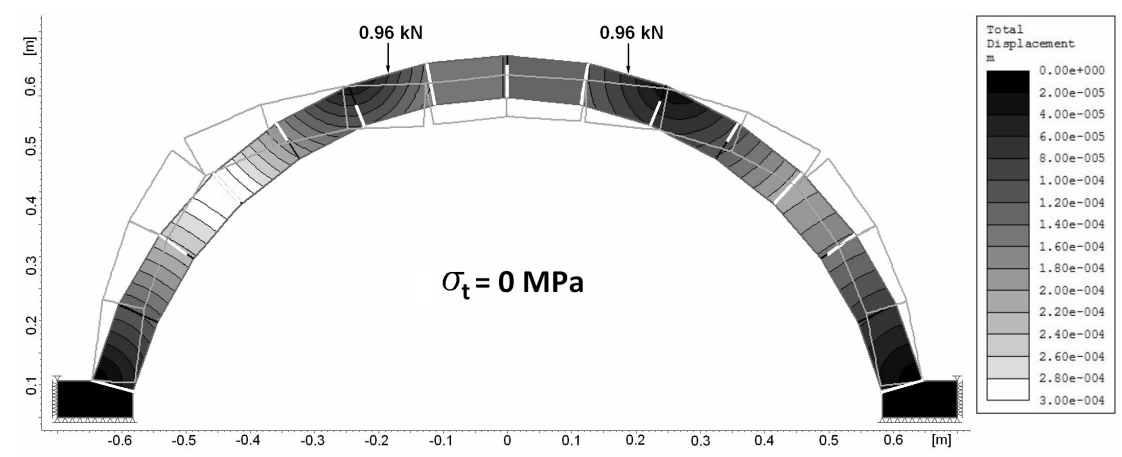

Fig. 2. Failure of an arch which behaves as a masonry shell $\left(\sigma_{t}=0 \mathrm{MPa}\right)$

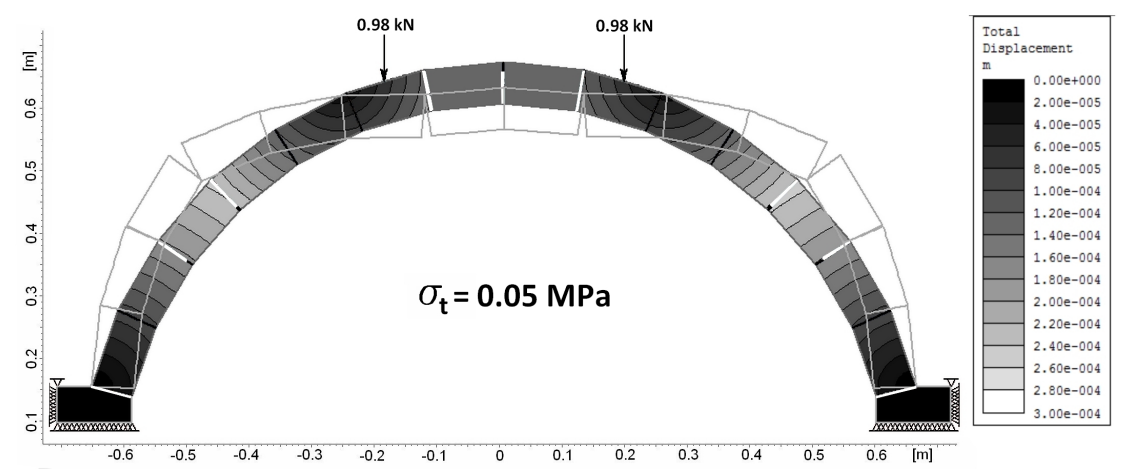

Fig. 3. Failure of an arch which behaves as a masonry shell $\left(\sigma_{t}=0.05 \mathrm{MPa}\right)$ 


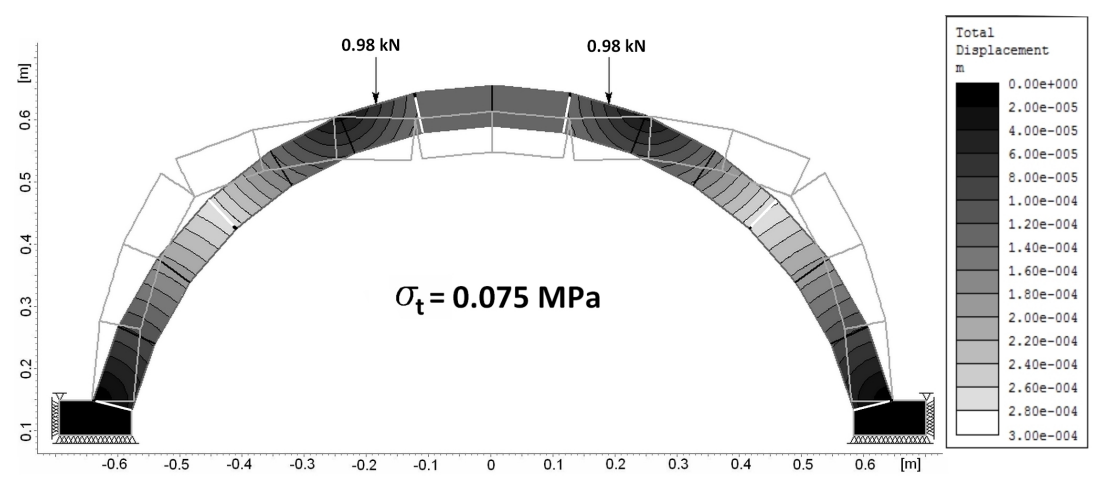

Fig. 4. Failure of an arch which behaves as a masonry shell $\left(\sigma_{t}=0.075 \mathrm{MPa}\right)$

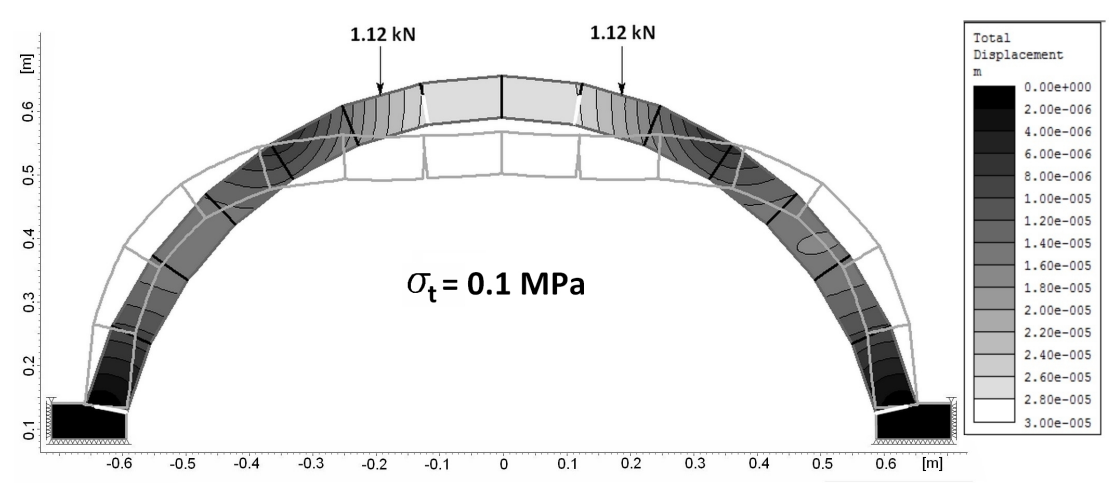

Fig. 5. Failure of an arch which behaves as a continuum shell $\left(\sigma_{t}=0.1 \mathrm{MPa}\right)$

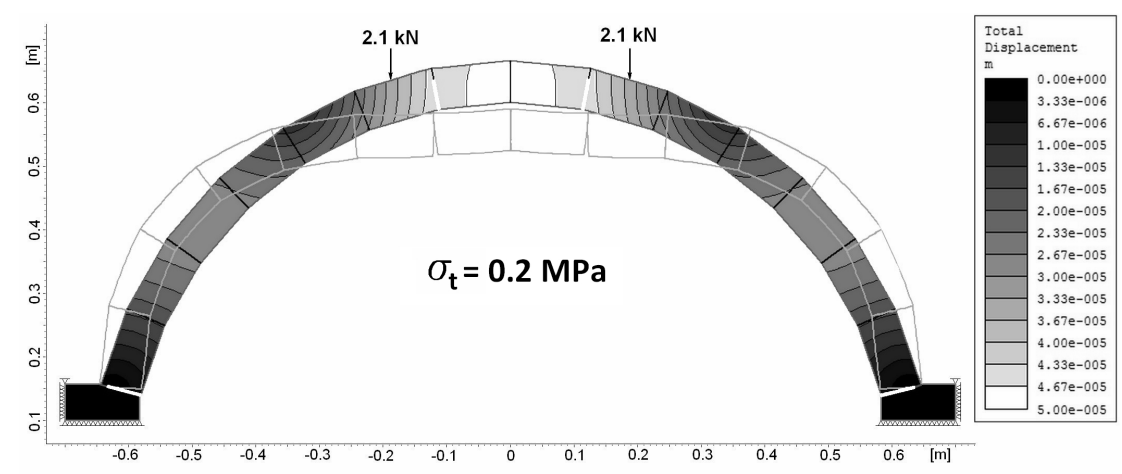

Fig. 6. Failure of an arch which behaves as a continuum shell $\left(\sigma_{t}=0.2 \mathrm{MPa}\right)$

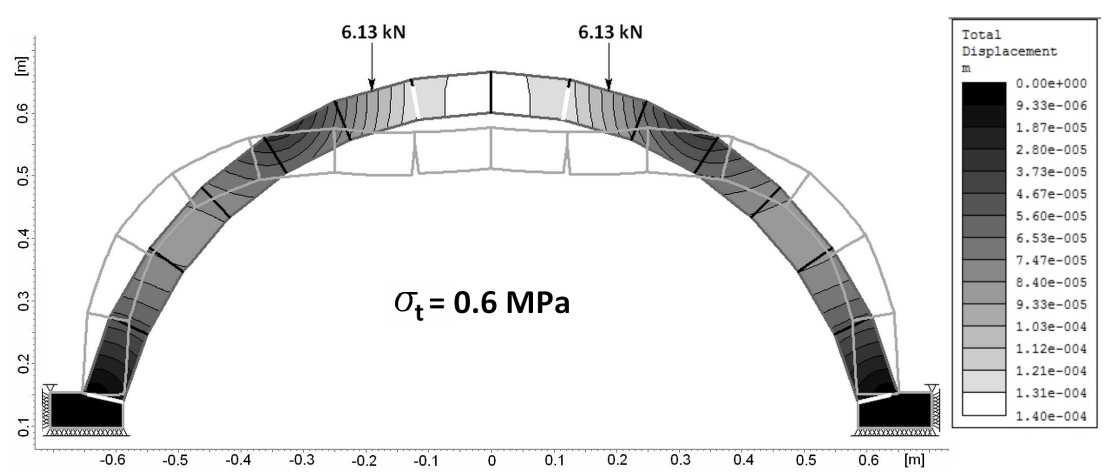

Fig. 7. Failure of an arch which behaves as a continuum shell $\left(\sigma_{t}=0.6 \mathrm{MPa}\right)$ 
Tab. 2. Effect of the tensile strength of the connections

\begin{tabular}{|c|c|c|c|c|c|c|c|c|}
\hline Tensile strength [MPa] & 0.00 & 0.025 & 0.05 & 0.075 & 0.10 & 0.20 & 0.30 & 0.60 \\
\hline Failure load [kN] & 0.96 & 0.98 & 0.98 & 0.98 & 1.12 & 2.10 & 3.15 & 6.13 \\
\hline Max displacement [mm] & 0.32 & 0.24 & 0.24 & 0.27 & 0.03 & 0.05 & 0.06 & 0.13 \\
\hline Number of cracked connections & 13 & 9 & 9 & 6 & 4 & 4 & 4 & 4 \\
\hline & \multicolumn{4}{|c|}{ ～Masonry shell } & \multicolumn{4}{|c|}{$\sim$ Continuum shell } \\
\hline
\end{tabular}

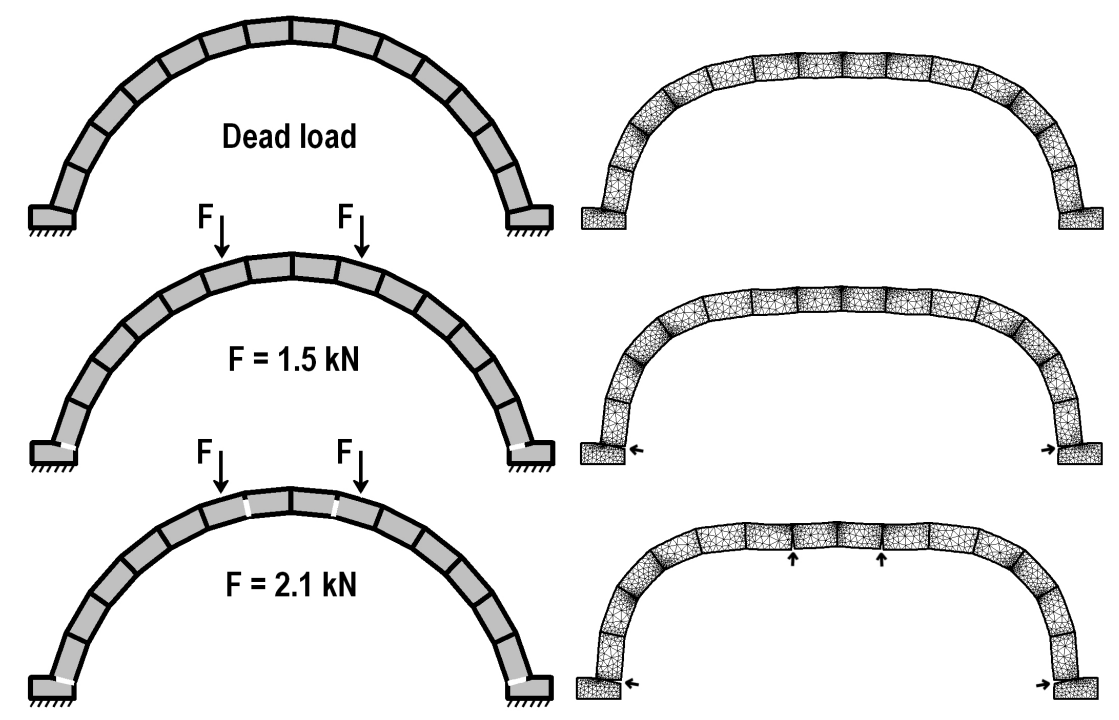

Fig. 8. Partly or entirely cracked connection (left) and deformed shape with the opened connections (right) in case of a continuum shell $(\sigma t=0.2 \mathrm{MPa})$

the range within which the structure works as a typical masonry shell or a continuum shells.

From the results it can be summarized that the mechanical behaviour of the structure changes considerably even in case of a small extent change of the tensile strength of the connections. Within the range where the arch works as a masonry shell the failure load stays in the same level. On the other hand, within the range where the structure works as a typical continuum shell the failure load and the maximum displacement increase linearly along the increase of the tensile strength.

Relying upon these findings, the tensile strength of the connections of the small scale laboratory model should be adjusted in between $0-0.075 \mathrm{MPa}$ in order to allow the model to behave as a masonry shell. In case of real size vaults the range of the masonry shell behaviour is much larger, and the bonding strength of the mortars are generally within this range.

\subsubsection{Behaviour of the structure}

Besides the failure load, tensile strength also determines the structural behaviour under loading and the failure mechanism as well. Fig. 8 and 9 represent the two different behaviours under loading, up to the failure. The left side of these figures shows the extent of the loads that are applied, and white lines mark the cracked parts of the connections within the original geometry. On the right side of these figures the deformed shape can be seen on which the partially opened connections are marked.
Fig. 8 presents the main phases how a continuum shell behaves. It can be seen, that four - i.e. the number of the degree of static indeterminacy plus one - hinges were necessary for the failure of the structure in accordance with the theory. Two connections opened at the abutments and two opened next to the upper two blocks. These hinges were formed symmetrically, and one after the other. After the tensile strength of the connection was exhausted, the connection was not able to bear extra moment. It was experienced that at this point the connections between the blocks cracked, and the joint behaved as if no tensile strength exists. In this case the structure - depending on the degree of static indeterminacy - can suffer brittle failure or it can start to behave as it would have an additional hinge. After the first two hinge had been formed, the moment was redistributed, and the following hinges were formed. On the other hand, in Fig. 9 it can be seen, that up to the failure of the arch the connections of which have no tensile strength, more partly or entirely opened connections were formed than in the previous case. These opened connections were not formed one after the other. They were formed simultaneously. It can be also observed that there were connections which cracked partly or entirely, however not all of the cracked connections were turned into hinges.

The accomplished finite element models draw attention to the facts that:

- in case of masonry vaults which have joints that pass through the direction of axis (i.e. the numerical modelling of which 


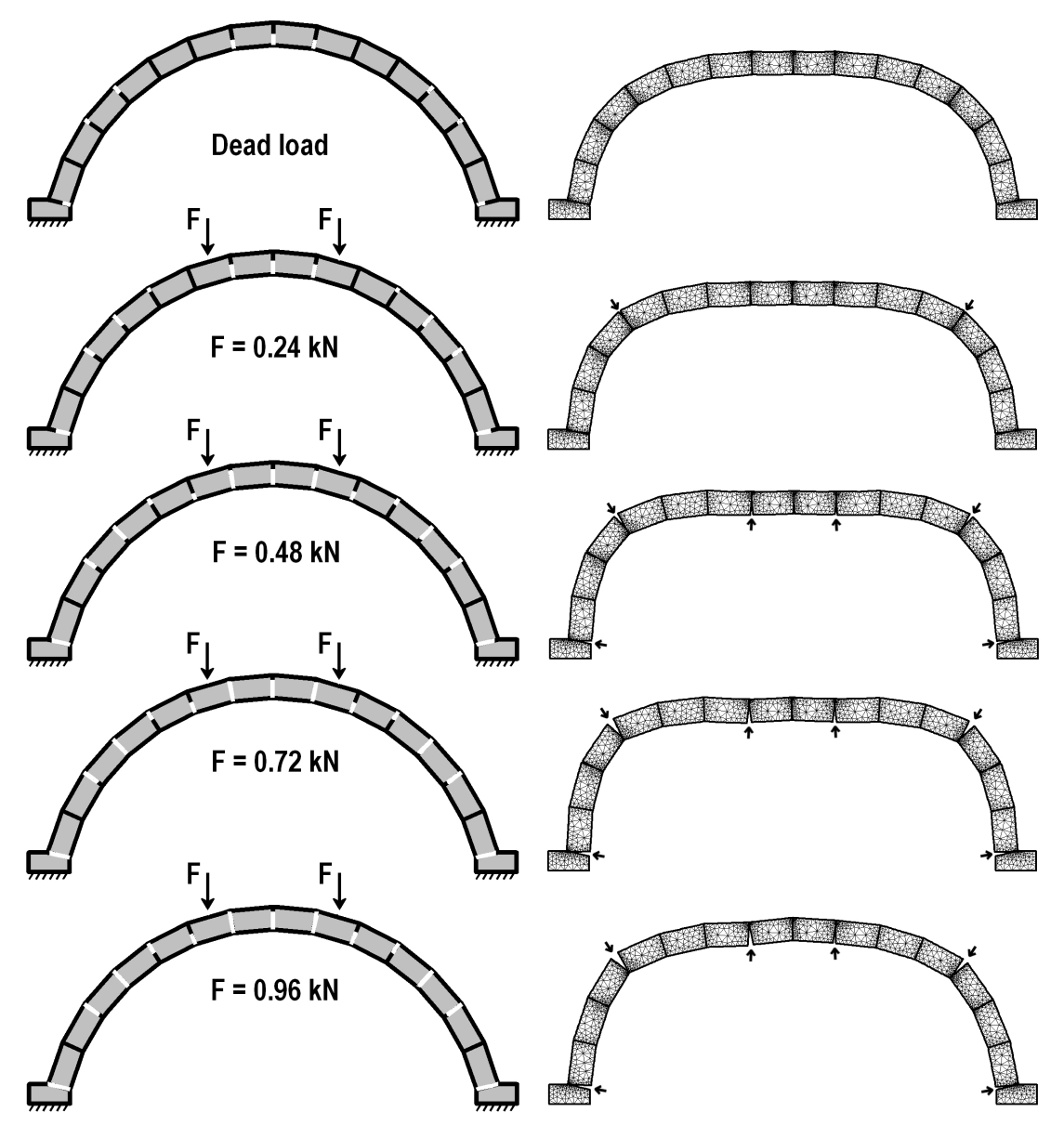

Fig. 9. Partly or entirely cracked connection (left) and deformed shape with the opened connections (right) in case of a masonry shell $(\sigma t=0 \mathrm{MPa})$

can be reduced to a two-dimensional task), the real behaviour may differ from some theoretical simplified method which calculate with plastic hinges,

- in case of these kinds of masonry vaults up to the moment of collapse several partly cracked and several partially opened connections are formed, and at the moment when the structure collapses, the masonry arch suddenly becomes a kinematic chain due to the hinges that have zero bending moment capacity,

- a cracked connection is not necessarily equal to the plastic hinge.

- Partly or entirely cracked connection (left) and deformed shape with the opened connections (right) in case of a continuum shell $\left(\sigma_{t}=0.2 \mathrm{MPa}\right)$

- Partly or entirely cracked connection (left) and deformed shape with the opened connections (right) in case of a masonry shell $\left(\sigma_{t}=0 \mathrm{MPa}\right)$

\section{Discussion}

The results showed that small-scale laboratory models of stone masonry arches can be analysed by means of numerical modelling. The Phase ${ }^{2}$ finite element program was able to analyse the structural behaviour with the application of joint ele- ments. Naturally, the validation of these results is necessary with laboratory experiments, and this will be the next phase of this project.

In these tests the simulations of the loads were comparable but significantly smaller than the typical loads of a 1:1 scale masonry structure. The results of these preliminary investigations indicate that the tensile strength of the connections has an important role in the stability of the structure. Naturally, the friction between the blocks of an arch has also a great influence on the general behaviour of the structure. It effects the most how many connections crack which effects the failure mechanism. Compared to other similar researches [11, 12, 14, 22] the focus of this project was rather on the behaviour of the structural elements than the determination of the global system between the displacements and the loads.

The paper also showed that it is necessary to analyze the behaviour of the arches under loading rather than only the ultimate loads. Further studies are needed to better understand the effect of load distribution when the effect of backfill is also taken into account. The effect of the thickness, the shape of the vault, the different material properties and the type of masonry will be a further focus area of the future research. 


\section{Conclusions}

FEM modelling $\left(\mathrm{Phase}^{2}\right.$ ) of the small-scale stone masonry arch showed that it is particularly important to select the materials scrupulously focusing on the bonding strength of the connections because the behaviour of the structure may differ considerably due to the small scale. Thus homogeneous rock types and lime mortar with small tensile strength are recommended to be used.

The results of the numerical modelling draw attention to the fact that the vaults that have been used from the ancient times are little understood in terms of their mechanical behaviour. The bonding strength of the connections influences the load-bearing capacity and the behaviour of the structure under loading significantly. The results of the numerical modelling also show that the formations of the partly cracked connections have a significant role in the formation of the failure of barrel vaults. Thus the behaviour of these cracked connections and their relationship to the theoretical plastic hinges require further investigations.

\section{References}

1 Gálos M, Vásárhelyi B, Közúti boltozott kóhidaink, Díszítô Építő Mú Terméskő, VII(2), (2005), 21-25. (in Hungarian).

2 Berkó D, Boltozatos kóhidaink, Mélyépítés, 5, (2003), 16-20. (in Hungarian).

3 Gubányi-Kléber J, Vásárhelyi B, A héhalmi boltozott kõhíd vizsgálata, Mélyépítés, 1, (2004), 16-20. (in Hungarian).

4 Orbán Z, Guttermann M, Assessment of masonry arch railway bridges using non-destructive in-situ testing methods, Engineering Structures, 31(10), (2009), 2287-2298, DOI $10.1016 /$ j.engstruct.2009.04.008

5 Orbán Z, Condition assessment and rehabilitation of masonry arch railway bridges, Concrete Structures, 7, (2006), 22-30.

6 Bögöly G, Görög P, A Bükkös patak boltozott kõhídjának vizsgálata, Mérnökgeológia-Kôzetmechanika, In: Török Á, Vásárhelyi B (eds.), Mérnökgeológia-Kőzetmechanika, Múegyetemi Kiadó; Budapest, 2010, pp. 34-44. (in Hungarian).

7 Bögöly G, Görög P, Seidl Á, Török Á, Gyöngyöspatai boltozott híd kõzetdiagnosztikai vizsgálata, Építmények védelme - Múemlékek védelme, In: Szalay L (ed.), Építmények védelme - Múemlékek védelme; Budapest, 2011, pp. 1-9. (in Hungarian).

8 Bögöly G, Görög P, Török Á, Diagnostics and stability analysis of stone masonry arch bridges, a case study from Hungary, 2nd wta-international phd symposium, In: Drochytka R, Bohus S (eds.), Building Materials and Building Technology to Preserve the Built Heritage, Academic Publishing CERM Ltd; Brno, 2011, pp. 98-107.

9 Bögöly G, Görög P, Török Á, Boltozott kóhidak diagnosztikai módszerei, Díszítő Építô Mú Terméskô, XIII(1), (2011), 32-36. (in Hungarian).

10 Melbourne C, Gilbert M, The behaviour of multiring brickwork arch bridges, The Structural Engineer, 73, (1995), 39-47.

11 Gilbert M, Smith CC, Hawksbee SJ, Melbourne C, Modelling Soilstructure interaction in masonry arch bridges, 7th International Conference on Arch Bridges, In: Radiae J, Kuster M, Savor Z (eds.), Proceedings of the 7th International Conference on Arch Bridges, SECON-CSSE; Zagreb, 2013, pp. 613-620.

12 Calaway P, Gilbert M, Smith CC, Influence of backfill on the capacity of masonry arch brides, Bridge Engineering, 165, (2012), 147-158, DOI 10.1680/bren.11.00038

13 Srisanthi VG, Keshav L, Kumar P, Jayakumar T, Finite Element and Experimental Analysis of 3D Masonry Compressed Stabilised Earth Block and
Brick Building Models against Earthquake Forces, Periodica Polytechnica Civil Engineering, 58(3), (2014), 255-265, DOI 10.3311/PPci.7443

14 Giordano A, Mele E, Luca AD, Modelling of historical masonry structures: comparison of different approaches through a case study, Engineering Structures, 24, (2002), 1057-1069, DOI 10.1016/S0141-0296(02)00033-0

15 Gubányi-Kléber J, Vásárhelyi B, Orbán Z, Seidl Á, Útügyi Müszaki Elôírás 813/2005, Magyar Útügyi Társaság, 2006. (in Hungarian).

16 Bögöly G, Borbély D, Görög P, Elókészítô vizsgálatok kóboltozat laboratóriumi modellezéséhez, Magyar Építőipar, 4, (2014), 141-145. (in Hungarian).

17 Vásárhelyi B, A történelmi Galíciai út Tokaj-hegyaljai szakasza és boltozott kóhídjai, Építés - Építészettudomány, 35(1), (2007), 117-135. (in Hungarian).

18 Bagi K, Bojtár I, Gálos M, A note on the role of internal structure of rocks in the deviations of compression strength results, Periodica Polytechnica Civil Engineering, 43(2), (1999), 169-178.

19 Török Á, Petrophysical and Sedimentological Analyses of Siklós Ornamental Limestones, S-Hungary, Periodica Polytechnica Civil Engineering, 43(2), (1999), 187-205.

20 Tóth AR, Orbán Z, Bagi K, Discrete element analysis of stone masonry arch, Mechanics Research Communications, 36(4), (2009), 469-480, DOI 10.1016/j.mechrescom.2009.01.001

21 Phase2 Theory Overview, Rocscience, 2014, http://www.rocscience. com/help/phase2/webhelp/theory/Theory_Overview.htm

22 Cavicchi A, Gambarotta L, Two-dimensional finite element upper bound limit analysis of masonry bridges, Computers and Structures, 84, (2006), 2316-2328, DOI $10.1016 /$ j.compstruc.2006.08.048 